\title{
SURVEY ON BACTERIAL CAUSES OF ENTERIC DISEASES IN YOUNG RABBITS IN ALEXANDRIA GOVERNORATE
}

\begin{abstract}
OLA.A.M.BASHA
Department of Bacteriology, Animal Health Research Institute, Alexandria Branch
\end{abstract}

\begin{abstract}
A total number of 50 samples from faecal material of rabbits suffering from enteritis were collected from different localities at Alexandria Governorate. Samples were collected as faecal swabs or intestinal content of freshly dead or slaughtetred rabbits aged 1-4 months. Bacteriological examination was done for isolation and identification of bacterial strains causing enteric affections in rabbits; the isolated microorganisms were E. coli, Proteus, Klebsiella, Pseudomonas aeruginosa, Clostridium perfringens, and Staph. aureus at 80, 18, 12, 6,6,4 \% respectivily. Serotyping of isolated E. coli were: O127, O169, O86, O1. Pathogenicity tests of isolated strains revealed that E.coli O127, O169 and Pseudomonas aeruginosa were the most pathogenic causing $100 \%$ mortality while E.coli_O1, Proteus, Klebsiella, and Clostredium perfringens caused $66.6 \%$ mortality, E.coli O1 and Staph. aureus caused mortality at 33.3\%. The inoculated rabbits showed general signs of enteric disease and trials for reisolation of inoculated strains were conducted. The sensitivity tests of the isolates revealed that Ciprofloxacin was the drug of choice for many of the isolates in this study.
\end{abstract}




\section{INTRODUCTION}

In Egypt, the industry of fattening rabbits plays an important role in facing the major public needs of animal proteins as rabbit's meat is characterized by its palatability and popularity. But this industry faces the enteric diseases which are responsible for high economic losses in rabbit's farms especially in the new born and weaned rabbits (Blance et al., 1991). So, interest has been focused on enteric bacteria as a cause of disease and mortality in young rabbits especially at $5-10$ weeks of age (Nikkels et al., 1976).

Many species of bacteria were incriminated as a cause of enteritis in rabbits but, E.coli was the most prevalent microorganism isolated from the rectum of rabbits suffering from diarrhea $(A z a b, 1992)$ and the strains from diarrhetic weaned rabbits, belonged to at least eight different serotypes of E.coli (Peeters et al., 1984). It was mentioned that, enterotoxigenic E.coli lead to infectious diarrhea in the world wide; while strains of E.coli which cause diarrhea in rabbits are the classical enteropathogenic E.coli (walf, 1997). In addition , proteus species were isolated from rabbits suffering from digestive diseases $(\mathbf{A l i}, \mathbf{1 9 8 3})$ and Klebsiella could be isolated from diseased or freshly dead rabbits with history of high mortality, diarrhea and lesions of septicemia (Hegazy et al., 1992). Pseudomonas aeruginosa was reported as a cause of infectious diseases of multiple aetiology in farmed rabbits (Loliger and Matthes 1989). In addition, toxins of Staph. aureus play a role of enteritis in rabbits as it is one of the most common causes of intestinal diseases of microbial origin in developing countries (Kumar et al., 1997). Cl.perfringens plays a role in rabbit enteritis depending on 
production of toxins type $\mathrm{E}$ which considered the etiological agent of rabbit enteritis even if various authors failed to isolate it from the caecum of diseased rabbits (Cocchi ,M.et al., 2008).

The aim of this study was planned to investigate the bacterial causes of diarrhoea in young rabbits to help farmers to avoid troubles that may face and the economic losses that may arise and the sensitivity tests to different antibiotics drugs.

\section{MATERIAL AND METHODS}

\section{1- Collection of samples:}

All samples were collected from rabbit's aged $1-4$ months from farms of different localities at Alexandria governorate . A total number of 50 sample of faecal material (Table ,1) were collected either from intestinal content of freshly slaughtered or freshly dead rabbits or swabs from rabbits with enteric disorder as the symptoms of digestive problems or enteritis in rabbits are simple and constant manifested by decrease in food intake, skin dehydration and quantities of liquid feaces soiling the hind quartes of the rabbit (Jones and Duff, 2001).

Table (1): Faecal samples collected from different localities at Alexandria Governorate.

\begin{tabular}{||l||c||c||}
\hline \multicolumn{1}{|c|}{ Origin } & \multicolumn{1}{|c||}{ Types of samples } & No. of samples \\
\hline \hline \multirow{2}{*}{ Abbis } & Faecal swab & 12 \\
\hline Elamria & Faecal material & 7 \\
\hline Elmaamora & Faecal material & 10 \\
\hline Nubaria & Faecal material & 8 \\
\hline Elmalaha & Faecal swabs & 13 \\
\hline Total & & $\mathbf{5 0}$ \\
\hline
\end{tabular}

$\overline{\text { Kafrelsheikh Vet. Med. J. Vol. } 10 \text { No. } 1 \text { (2012) }}$ 


\section{2- Bacteriological examination:-}

All samples were transferred to the lab where the faecal swabs were kept in tubes with transporting media or about 1-2 gm of the faecal material from diarrhoeic slaughtered rabbits or freshly dead rabbits were obtained from intestinal content.

Each sample was divided into 2 parts. The first part was inoculated into trypticase broth and tetrathionate broth then incubated aerobically at $37^{\circ} \mathrm{c}$ for $24-48$ hour. The second part was inoculated into thioglycolate broth and then incubated anarebically in an anaerobic Gas pack jar at $37^{\circ} \mathrm{c}$ for $24-48 \mathrm{hrs}$.

Aerobically incubated broth were streaked onto nutrient agar, macConkey's agar, eosin methelene blue agar, mannitol salt agar, and S.S.agar to be incubated at $37^{\circ} \mathrm{c}$ for $24-48$ hours, also subculturing from thioglycolate broth onto TSC agar (Tryptcase sulphate cycloserine) was performed and incubated anarobically in anaerobic Gas pack jar at $37^{\circ} \mathrm{c}$ for $24-48$ hours.

Isolated purified colonies were kept onto slope agar then transfered to be preserved on semisolid nutrient agar for further identifications.

The identification of aerobic cultures colonies was carried out according to Edwards and Ewing (1972), the cultures were examined morphologically and microscopically using Gram's staining technique then the isolates were subjected to series of biochemical tests. The colonies of the plates of anaerobic incubation were examined morphologically and after Gram staining microscopically suspected strains were subjected to biochemical identification according to Cruickshank et al.(1975) and Koneman et al.(1988). 


\section{3- Serological Tests:}

E.coli were subjected to serological identification according to (Edwards and Ewing, 1972). Agglutination tests were primarily carried out using glass slide technique. A small drop of polyvalent E.coli antiserum was thoroughly mixed onto a clean dry slide with a small part of the suspected colony. The presence of any evidence of clumping or grainy appearance indicate a positive agglutination test. A control suspension was similarly prepared at the other end of the glass slide by using sterile saline solution instead of E.coli. When a positive reaction was observed with one of the polyvalent sera, testing of the corresponding monovalent sera was carried out.

\section{4- Pathogencity tests:}

Thirty five rabbits of 4-6 weeks old were used in the experimental infection which was performed to study pathogenicity of the isolated microorganisms. The rabbits of choice were apparently healthy obtained from commercial rabbit farms in Alexandria Governorate.

The rabbits were kept in cages and observed for a week. Random samples of 5 rabbits were slaughtered and examined bacteriologically to be sure that they are healthy and free from diseases (control). Other rabbits were classified into 10 groups; each group contain 3 rabbits which were given orally one of the isolated microorganism at a dose of $0.5 \mathrm{ml}$ of $3 \times 10^{8} \mathrm{cfu} / \mathrm{ml}$ while the last group was given sterile normal saline (Cantey and Black, 1977). During the observation period (one month) clinical signs, post mortum lesions were recorded and trials for reisolations of inoculated strains were conducted. 


\section{5- Antimicrobial sensitivity tests:}

Disc diffusion method was done according to Finegold and Martin (1982) by subculturing from the isolated strains broths on Muller Hinton agar, and using antibiotic discs which include: Nitrofuratoin $(300 \mu \mathrm{g})$, Gentamycin $(10 \mu \mathrm{g})$, Amoxycillin $(10 \mu \mathrm{g})$, Cefotaxime $(30 \mu \mathrm{g})$, Amoxicillin clavulanic acid $(30 \mu \mathrm{g})$, Ofloxacin $(5 \mu \mathrm{g})$, polymixine B (300 $\mu \mathrm{g})$, Ciprofloxacin $(5 \mu \mathrm{g})$, Neomycin $(300 \mu \mathrm{g})$, Erythromycin $(15 \mu \mathrm{g})$, Trimethoprime $(25 \mu \mathrm{g})$ and Ampicillin $(10 \mu \mathrm{g})$. The result were interpreted according to Quninn et al., (1994).

\section{RESULTS}

Table (2): Bacteria associated with Enteritis in Rabbit from Farms at Alexandria Governorate:

$($ Number of samples $=50)$

\begin{tabular}{||c||c||c|}
\hline Isolates & No. of isolates & $\%$ \\
\hline \hline E.Coli & 40 & 80 \\
\hline Proteus & 9 & 12 \\
\hline Klebsiella & 6 & 6 \\
\hline Ps.aeruginosa & 3 & 4 \\
\hline Cl. perfringens & 3 & - \\
\hline Staph. aureus & 2 & \\
\hline Salmonella & - & 6 \\
\hline Total & $\mathbf{6 3}$ & \\
\hline
\end{tabular}

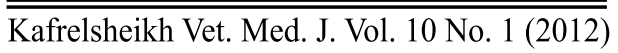


Survey On Bacterial Causes Of Enteric Diseases In Young Rabbits In ...

Table (3): Biochemical Identification of Isolated Bacteria:

\begin{tabular}{|c|c|c|c|c|c|c|c|c|c|c|c|}
\hline \multicolumn{12}{|c|}{ Negative gram stain bacteria } \\
\hline & Motility & Indol & Nitrate & $\begin{array}{l}\text { H2S } \\
\text { prod. }\end{array}$ & Oxidase & Catalase & se | citrate & MR & V.P. & ureas & \begin{tabular}{c|c} 
e & $\begin{array}{c}\text { Lactose } \\
\text { ferm. }\end{array}$
\end{tabular} \\
\hline E.coli & + & + & + & - & - & + & - & + & - & - & + \\
\hline Proteus & + & \pm & + & + & - & + & \pm & + & \pm & + & - \\
\hline Klebsiella & - & - & + & - & - & + & + & - & + & + & + \\
\hline Ps.aeruginosa & + & - & + & - & + & \multicolumn{2}{|c|}{+} & - & - & + & - \\
\hline \multicolumn{12}{|c|}{ Positive gram stain rod } \\
\hline \multirow{2}{*}{ Cl.perfringens } & \multirow{2}{*}{ Indor } & \multicolumn{2}{|c|}{$\mathrm{H} 2 \mathrm{~S}$} & urease & \multirow{2}{*}{\multicolumn{2}{|c|}{ Haemolysis }} & manitol & Glucose & \multicolumn{2}{|c|}{ Lactose } & Maltose \\
\hline & & \multicolumn{2}{|r|}{+} & \pm & & & - & + & \multicolumn{2}{|c|}{+} & - \\
\hline \multicolumn{12}{|c|}{ Positive gram stain cocci } \\
\hline \multirow[b]{2}{*}{ Staph.aureus } & \multirow{2}{*}{\begin{tabular}{|c|}
$\begin{array}{c}\text { Cell } \\
\text { arrangement }\end{array}$ \\
clusters
\end{tabular}} & \multicolumn{2}{|c|}{ catalase } & coagulase & \multicolumn{2}{|c|}{$\begin{array}{c}\text { Growth at } \\
9.6\end{array}$} & pigment & Haemolysis & \multicolumn{2}{|c|}{$\begin{array}{l}\text { Mannitol } \\
\text { Ferm. }\end{array}$} & O.F. medium \\
\hline & & \multicolumn{2}{|r|}{+} & + & \multicolumn{2}{|l|}{+} & $\begin{array}{l}\text { White, } \\
\text { golden } \\
\text { yellow }\end{array}$ & + & \multicolumn{2}{|c|}{+} & + \\
\hline
\end{tabular}

Table (4):Serotypes of E.coli isolated from rabbits suffered from enteritis:

\begin{tabular}{||l||c||c|}
\hline \multicolumn{1}{|c|}{ E.coli serotypes } & No. & $\%$ \\
\hline \hline E.coli 0127 & 5 & 12.5 \\
\hline E.coli 0169 & 5 & 12.5 \\
\hline E.coli $O 86$ & 10 & 25 \\
\hline E.coli $O 1$ & 5 & 12.5 \\
\hline Un typable E.coli & 15 & 37.5 \\
\hline
\end{tabular}

Table (5): Experimental infection of $4-6$ weeks old rabbits with pathogenic enteric microorganisms.

\begin{tabular}{|c|c|c|c|c|}
\hline Inoculated M.O & No. of group & No. of injected rabbits & Total number of deaths & $\%$ deaths \\
\hline E.coli 0127 & 1 & 3 & 3 & 100 \\
\hline E.coli 0169 & 2 & 3 & 3 & 100 \\
\hline E.coli 086 & 3 & 3 & 1 & 33.3 \\
\hline E.coli $O 1$ & 4 & 3 & 2 & 66.6 \\
\hline Proteus & 5 & 3 & 2 & 66.6 \\
\hline Klebsiella & 6 & 3 & 2 & 66.6 \\
\hline Ps.aeruginosa & 7 & 3 & 3 & 100 \\
\hline St. aureus & 8 & 3 & 1 & 33.3 \\
\hline Cl.perfringens & 9 & 3 & 2 & 66.6 \\
\hline Control & 10 & 3 & 0 & 0 \\
\hline
\end{tabular}

Kafrelsheikh Vet. Med. J. Vol. 10 No. 1 (2012) 
Table (6): Interpretation of zones of inhibition in agar diffusion method for antibacterial susceptability:

\begin{tabular}{|c|c|c|c|c|c|c|c|c|c|}
\hline \multirow{2}{*}{ Antibacterial agent } & \multicolumn{9}{|c|}{ Inhibition zones of isolated bacteria } \\
\hline & $\begin{array}{l}\text { E.coli } \\
\text { O127 }\end{array}$ & $\begin{array}{l}\text { E.coli } \\
\text { O169 }\end{array}$ & $\begin{array}{c}\text { E.coli } \\
\text { O86 }\end{array}$ & $\begin{array}{c}\text { E.coli } \\
\text { O1 }\end{array}$ & proteus & klebsiella & \begin{tabular}{||c} 
Pseudomonas \\
aeruginosa
\end{tabular} & $\begin{array}{l}\text { Staph } \\
\text { aureus }\end{array}$ & $\begin{array}{l}\text { Clostridium } \\
\text { perfringens }\end{array}$ \\
\hline Nitrofuration $300 \mu \mathrm{g}$ & S & HS & S & HS & $\mathrm{IM}$ & $\mathrm{S}$ & $\mathrm{R}$ & $\mathrm{R}$ & IM \\
\hline Gentamycin $10 \mu \mathrm{g}$ & $\mathrm{S}$ & HS & HS & HS & $S$ & IM & $\mathrm{S}$ & IM & $\mathrm{R}$ \\
\hline Amoxicillin $10 \mu \mathrm{g}$ & $\mathrm{IM}$ & $\mathrm{IM}$ & IM & IM & $\mathrm{R}$ & $\mathrm{R}$ & $\mathrm{R}$ & IM & $\mathrm{S}$ \\
\hline Cefotaxime $30 \mu \mathrm{g}$ & $\mathrm{R}$ & HS & $\mathrm{R}$ & HS & IM & IM & $\mathrm{R}$ & IM & $\mathrm{S}$ \\
\hline $\begin{array}{l}\text { Amoxicillin clavulanic } \\
\text { A. } 30 \mu \mathrm{g}\end{array}$ & IM & IM & IM & $\mathrm{S}$ & $\mathrm{R}$ & IM & $\mathrm{IM}$ & IM & $\mathrm{IM}$ \\
\hline Ofloxacin $5 \mu \mathrm{g}$ & HS & HS & HS & HS & $\mathrm{R}$ & $\mathrm{IM}$ & $\mathrm{S}$ & $\mathrm{IM}$ & $S$ \\
\hline Polymxin B.5 $\mu \mathrm{g}$ & IM & S & S & S & $\mathrm{R}$ & IM & IM & IM & S \\
\hline CiproFloxacin $5 \mu \mathrm{g}$ & HS & S & HS & $S$ & $S$ & S & HS & $\mathrm{S}$ & IM \\
\hline Neomycin $30 \mu \mathrm{g}$ & $\mathrm{IM}$ & S & HS & IM & IM & IM & IM & IM & $\mathrm{R}$ \\
\hline Trymethoprime $5 \mu \mathrm{g}$ & $\mathrm{R}$ & HS & $\mathrm{R}$ & $\mathrm{S}$ & $\mathrm{R}$ & IM & $\mathrm{R}$ & IM & $\mathrm{R}$ \\
\hline Nalidixic Acid $30 \mu \mathrm{g}$ & $\mathrm{S}$ & $\mathrm{R}$ & HS & $\mathrm{R}$ & $\mathrm{R}$ & IM & $\mathrm{R}$ & $\mathrm{R}$ & $\mathrm{R}$ \\
\hline Sulphamexazole $20 \mu \mathrm{g}$ & $\mathrm{R}$ & $\mathrm{R}$ & $\mathrm{R}$ & $\mathrm{R}$ & IM & $\mathrm{R}$ & $\mathrm{R}$ & $\mathrm{R}$ & $\mathrm{R}$ \\
\hline
\end{tabular}

High sensitive $=$ HS $=++++$

\begin{tabular}{cc} 
Sensitive $=\mathrm{S}=+++$ & Intermediate $=\mathrm{IM}=+++$ \\
\hline \hline Kafrelsheikh Vet. Med. J. Vol. 10 No. 1 (2012)
\end{tabular}

Resistant $=\mathrm{R}=$ 


\section{DISCUSSION}

Enteritis is the major cause of diseases in commercial rabbit industry. Diet, stress and management factors are known to affect the incidence and the spread of enteric disease. The rapid effect of these factors could be related to changes in the treatment and prophylactic protocols used in the farms (Boucher and Nouaille 1999).

\section{Incidence of isolation:}

Isolation and identification of bacteria from examined samples revealed that, most conditions of diarrhea in rabbits are due to the infection by Enterobacteriacea while Ramirez et al., (2005) found that the most conditions of diarrhea in rabbits is multifactor.

And in this research the most prevalent bacteria was E.coli followed by Proteus, Klebsiella, then Pseudomonas aeruginosa, Clostridium perfringens and finally, Staph.aureus at an incidence $80 \%$, $18 \%, 12 \%, 6 \%, 6 \%$, and $4 \%$ respectively (Table , 2 ).

The high ratio of E.coli was similar to that obtained by Abdel Rhman et al., (2005) 80\%, but higher than that obtained by Abdel Gwad (1988) 33\%, Blanco et al., (1994) 74\%, Abdel- Nasser (1998) 27.6\%, and Azhar et al., (2009) 45\%. The incidence of Proteus (18\%), Klebsiella (12\%), Pseudomonas aeruginosa (6\%) were higher than that obtained by Al-Shaimaa (2007), who isolated them at 14.8\%, 7.4\%, $2.1 \%$ respectively. Staph. aureus was isolated at $4 \%$, this was lower than that obtained by Azhar et al., (2009) 20\%.Cl.perfringens was isolated at 6\% which is lower than that obtained by Abdel- Rhman et al., (2007) where they recorded Cl.perfringens in diarrhotic rabbits at $33.75 \%$. 
Table (3) illustrated the biochemical tests characteristic for different isolates that in agreed with Abdel-Rhman et al., (2007) AlShaimaa (2007), and Azhar et al., (2009).

Concerning serotyping (Table,4) illustrated that 25 out of 40 isolate of E.coli were pathogenic and represented as $12.5 \% \mathrm{O} 127$, 12.5\%O169, 25\%O86, 12.5\% O1 while Al-Shaimaa (2007) typed E.coli as O111, O114, O125 But Abdel-Rhman et al., (2005) typed E.coli as O26, O44, O59, O114, O126, O127, O128.

It is enterest that in pathogenicity tests (Table ,5) revealed that E.Coli O127, E.Coli O169, and Pseudomonas aeruginosa were found to be highly pathogenic to rabbits, while isolated E.Coli O1, Proteus, Klebsiella, and CL.perfringens caused mortality rate 66.6\%, E.Coli 086 and Staph . aureus were the less pathogenic in this study, they cause mortality rate at $33.3 \%$. Compos et al.,(1994) reported that E.coli serotypes may classified as EPEC causing out breaks of diarrhea, while Roa and Char (1986) studied 232 strains of E.Coli from rabbits and identified different $\mathrm{O}$ groups of E.Coli and some of which were of zoonotic importance.

In table (6), It was found that E.coli serotypes were sensitive to Nitrofuratoin,Gentamycin, Ciprofloxacine but were resistant to Sulphamexazole and that agree with Al-Shaimaa (2007) who found O114, O125 were highly resistant to Sulphamexazole.

It was noticed that Proteus isolates were sensitive only to Gentamycin and Ciprofloxacin but resistant to many antibiotics. klebsiella were sensitive to Ciprofloxacin and NitroFuratoin but resistant to Amoxicillin this result is nearly similar to that reported by Dhand et al.,(2001). 
Pseudomona $s$ aeruginosa reported high resistance to many antibiotics, while it was highly sensitive to Ciprofloxacin, Sensitive to Gentamycin and Ofloxacin.

Ciprofloxacin was the drug of choice for Staph aureus which reported high resistance to other types of antibiotics.

Cl.Perfringens was sensitive to Amoxicillin, Polymxin B, and Ciprofloxacin but resistant to Nalidixic acid, Gentamycin and Neomycin and these agreed with that reported by Abdel-Rhman et al., (2007).

Finally, it was recommended that, efforts must be continued to detecte causes of diarrhea in rabbits with improving the diagnosis and hygienic measures to help prevention of the disease in weaned rabbits.

Paying attention to the use of antibiotics is recommended to be of value in treatments.

\section{REFERENCES}

- Abdel-Gwad, A.M. (1988): Some studies on Enterobateriacea in rabbits. Master degree in poultry Diseases veterinary medicine, Assiut University.

- Abdel-Nasser, A.H.T; Ali, L.; Hassanein, Z.A.; Saad, A.E. (1998): Current status on bacterial and parasitic agents involved in rabbit enteritis in Northen Egypt. J.vet. Sci.32: 79 -94.

- Abdel - Nasser, A.H.T; Mettias, K.N.; Saad, A.E; Ali, L. (1998): Preparation of E-Coli bacterins from two pathogenic serotypes isolated From rabbits. Egypt. J. vet. sci. 32: 67 -77. 
- Abdel - Rahman, A.A.; Hamed, N.A; Mostafa; F.A. (2005): Isolation and pathogenicity of intestinal pathogens associated with the enteritis complex in rabbits with special reference to Escherichia coli and Salmonella. Assiut vet.Med.J.51 (106): 180 - 197.

- Abdel-Rahman, A.A;Neveen A.A.; Fatma, A.M. (2007): Detection of the prevalence and pathogenicty of Clostridium perfringens and Clostridium spiroforme associated diarrhoea in rabbits. Assiut vet. Med. J. 53 (112): $296-311$.

- Ali, A.B. (1983): Studies on Enterobacteriaceae in rabbits in province. Thesis M.V.SC., Fac. vet. Med. Zagazig univ.

- Al - Shaimaa, A.M. (2007): Bacteriological studies on Enteric microorganisms in rabbits. Thesis M. V. Sc., Fac. vet. Med. Beni- Suif Univ.

- Azab, Y.R.A. (1992): Characterization of Enterobacteriaceae in rabbits. Thesis M.V.SC., Fac.vet.Med.Alexandria univ.

- Azhar M.H.; Neven A.E.; and Eman M.A.E.(2009): Etiological studies of enteritis in commercial rabbits. Ass. vet. Med. J. vol. 55 No 123: $226-235$.

- Blance, J.; Blanco, M.; Blanco, J. I. and Gonzalez, E.A. (1991): Entertoxins, colonization Fctors and serotypes of enterogoenic E.coli from human and animals. Microbiol.Sem, 7: $57-72$.

- Blanco, J.E.; Blanco, M.; Blanco, J.; Rioja, L. and Ducha, J. (1994): Serotypes, toxins and antibiotic resistance of E.coli strains isolated from diarrhoeic and healthy rabbits in spain vet. Microbiol. (38) $193-201$. 
- Boucher, S. and Nouaille, L.(1999): Klebsiella pneumoniae infection in rabbits, Study of 71 cases on rabbit farms in the loire region, France. Point veteriaire.30 (203): $645-650$.

- Campos,L.C.; whittam, T.S.; Gomes,T.A.T.; Andrade, J.R.C. and Traboulsi, L.R. (1994): Escherichia Coli serogroup O111 includes several clones of diarrhoeagenic strains with different virulence properties. Infect.Immun.62:3282 - 3288 .

- Cantey, J.R. and Blake, R.K.(1977): Diarrhea due to E.coli in the rabbit: novel mechanism.J.infect. Dis. 135(3): 454 - 462.

- Cocchi,M.; Drigo, I.;Bacchin, C.;Bano, L.; Marcon, B.; Angoletti, F. (2008): Toxin - Genotyping of Clostridium perfringens strains isolated from rabbits with enteric disease. World rabbit congress-June 10-13, 2008-Verona-Italy 921-924.

- Cruickshank, R.; Duguid, J. p.; Marmion, B.P. and swain, R.H.A. (1975): Textbook of medical microbiology. $11^{\text {th }}$ ed. The English language book society and Churchill living stone. Edinburgh and Newyork.

- Edwards, P.R. and Ewing, W.H. (1972): Identification of Enterobacteriaceae 3 rd Minnea polis, Burgess publishing, co.

- Dhand, N.K.;Saini.; Sharma, D.R. and Sandhu, K.S. (2001): Acute baterial pneumonia due to klebsiella pneumoniae in Angora rabbits. Ind.J.Comp.Microbiol, Jmmunobiol. Infec. Dis. 22 (2): 177. 
- Finegold, S.M. and Martin, W.T.(1982): Diagnostic Microbiology $6^{\text {th }}$ ed. C. V. Mosbyco. U.S.A.

- Hegazy, A.M.; El-Taher, A.M. and Ali, A.B. (1992): Bacterial causes of enteritis, diarrhea and mortality in rabbits. J. Appl. Sci. 7 (4): $602-611$.

- Jones, J.R. and J.R.Duff (2001): Rabbit epizootic enterocolitis. Veterinary Record, 149 (17), 532.

- Koneman, E.; Allen, S; Damsel, ver and Somme's, H. (1988): Colour Atlas and textbook of Diagnostic Microbiology 2 NDJ.Blip. Co.London.

- Krumpernam,P.H. (1983): Multiple antibiotic resistance indexing E.coli to identify risk sources of Fecal contamination of Foods. Appl.Enviromental Microbiol., 46: 165 - 170.

- Kumar, S.; Shukla, Y.N.; Lavania, u.c.; Sharma, A.; and Singh, A.K. (1997): Medicinal and Aromatic plants: Prospects for India.J.Med. Arom. Pl.Sci.19(2): 361 - 365.

- Loliger, H.C. and Matthes, S. (1989): Infections diseases of multiple aetiology in small animals of economic importance (Furbearing animals and Farmed rabbits. Berliner $u b=n$ Muchener Tierarztliche wochenscrift. (1): $364-371$.

- Nikkels,R.J.;Mullink, J.W. and Vanliet, J.C.(1976): An outbreak of rabbit enteritis: Pathological and microbiological Findings and possible therapeutic regime. Lab. Anim. 10 (3): 195-8. 
- Paul.,S.;R.L.,Bezbarauh, M.K.Roy and A.C. Ghosh (1997): Multiple antibiotic resistance (MAR) index and its reservation in ps.aeruginosa leter of Appl.Microbiol., 24: 169 - 171.

- Peeters, J. E.; Geeroms, R.and Glorieux, B. (1984): Experimental E.coli entropthy in weaning rabbits. Clinical manifestation and pathological Findings.J.Comp.Pathol.(4): 521 - 528.

- Quninn,P.J.,Carte, M.E.; Markery, B.K. and Carter, G.R. (1994): Clinical vet.Micro.year book - wolf publishing - Europlimited.

- Ramirez, K.; Huerta, R.; Oswald, E.; Garcia, Torar, C.; Hernandez, J. M. and Navarro, Garcia, F.(2005): Role of ESPA and intimin in expression of proinflamatory cytokines from entrerocytes and lymphocytes by rabbit enteropathogenic E.coli infected rabbits. IAnfec.Immen. 73 (1): 103-113.

- Rao, M.R.K. and Char, N.L.(1986): Enterobacteriaceae isolated from pathological condition of laboratory animals. Ind.vet.J.63 (3): $179-182$.

- Walf, M.W. (1997): Occurance, distribution and association of O and H. serogroups, colonization factors antigens and toxins of enterotoxogenic E.coli Clin. Microbiol. Rev. 10 (4): 569 - 584. 
استقصاء الأسباب البكتيرية للأمر اض المعوية فى الأر انب الصغيرة فى محافظة الإسكندرية

أجريت هذه الدراسة على عدد 50 من الأرانب التى تتراوح أعمارها من 1-4 شهور وكانت تعانى من الإسهال والنزلات المعوية و قد نم تجميع عينات البراز للفحص البكتريولوجى فكانت أما مسحات أو عينات براز من أرانب نم ذبحها اضطراريا او نفقت حديثا. ونم أخذ العينات من مناطق مختلفة بمحافظة الاسكندرية. أنتج الفحص البكتريولوجى عزل ميكروبات الايشيرشيا كولاى، البروتيس، الكلبسيلا، السودوموناس ارجينوزا، الكلوسترديم بيرفرنجنز، والميكروب الذهبى العنقودى بنسب :80 18-12-6-6-4 \% على التوالى ولم ينم عزل ميكروب السلمونيلا فى هذه الدراسة. تم إجراء الاختبارات السيرولوجية لميكروبات الايشيرشيا كولاى حيث تواجدها كان الاعلى نسبة فى المعزولات فصنفت سيرولوجيا. وتم فحص ضراوة العترات المصنفة من الميكروب القولونى O127 -

$$
.0169-086-01
$$

والعترات الاخرى المعزولة على أرانب عمر 4-6 اسابيع فكانت نسبة الوفيات 100\% فى حالة الميكروبات O127 - O169 و السودوموناس ايروجينوزا بينما وصلت الى6. 66\% فى حالة ميكروباتO1 - البروتيس - الكلبسيلا - والكلوسترديم بيرفرنجنز , على الجانب الاخر وصلت نسبة الوفيات الى 333\% فى حالة الميكروب O86 والميكروب العنقودى الذهبى. هذا و قد تم تسجيل الاعراض الاكلينيكية و الفحص التشريحى بعد الوفاة و بإجراء اختبارات الحساسية على العترات المعزولة تبين ان معظم الميكروبات لديها حساسية للسييروفلوكساسين لكن لوحظ ان المعزولات لديها مقاومة واضحة لكثير من المضادات الحيوية المستخدمة لذا يجب انتقاء علاجات فعالة من اجل الحصول على النتيجة المطلوبة لمقاومة المرض. 